\title{
Quantitative fidelity of Recent freshwater mollusk assemblages from the Touro Passo River, Rio Grande do Sul, Brazil
}

\author{
Alcemar R. Martelloํㅡ, Carla B. Kotzian² \& Marcello G. Simões ${ }^{3}$
}

1. Pós-graduação em Biodiversidade Animal, Universidade Federal de Santa Maria (UFSM), 97015-900 Santa Maria, RS, Brasil. (armartello@pop.com.br)

2. Laboratório de Malacologia, Departamento de Biologia, Universidade Federal de Santa Maria (UFSM). (modrizralok@hotmail.com)

3. Laboratório de Paleozoologia Evolutiva, Instituto de Biociências, UNESP, 18618-000 Botucatu, SP, Brasil. (btsimoes@ibb.unesp.br)

\begin{abstract}
This study represents one of the first contributions to the knowledge on the quantitative fidelity of the Recent freshwater molluscan assemblages in subtropical rivers. Thanatocoenoses and biocoenoses were studied in straight and meandering to braided sectors, in the middle course of the Touro Passo River, a fourth-order tributary of the Uruguay River, located in the westernmost part of the State of Rio Grande do Sul. Samplings were carried out through quadrats of $5 \mathrm{~m}^{2}$, five in each sector. A total area of $50 \mathrm{~m}^{2}$ was sampled. Samplings were also made in a lentic environment (abandoned meander), with intermittent communication with the Touro Passo River, aiming to record out-of-habitat shell transportation from the lentic communities to the main river channel. The results show that, despite the frequent oscillation of the water level, the biocoenosis of the Touro Passo River shows high ecological fidelity and undergoes little influence from the lentic vicinal environments. The taxonomic composition and some features of the structure of communities, especially the dominant species, also reflect some ecological differences between the two main sectors sampled, such as the complexity of habitats in the meandering-sector. Regarding the quantitative fidelity, $60 \%$ of the species found alive were also found dead and $47.3 \%$ of the species found dead were also found alive, at river-scale. However, $72 \%$ of the dead individuals belong to species also found alive. This value might be related with the good rank order correlation obtained for live/dead assemblages. Consequently, the dominant species of the thanatocoenoses could be used to infer the ecological attributes of the biocoenoses. The values of all the indexes analyzed were very variable in small-scale samplings (quadrat), but were more similar to others registered in previous studies, when they were analyzed in a station and river scale.
\end{abstract}

KEYWORDS. Freshwater mollusks, taphonomy, death assemblages, life assemblages.

RESUMO. Fidelidade quantitativa de associações de moluscos límnicos recentes na bacia do rio Touro Passo, Rio Grande do Sul, Brasil. O presente estudo teve como objetivo apresentar uma das primeiras contribuições ao conhecimento sobre a fidelidade quantitativa de associações de moluscos recentes em rios subtropicais. Tanatocenoses e biocenoses foram estudadas em seções retilínea e meandrante tendendo a anastomosada, no curso médio do rio Touro Passo, um tributário de $4^{\mathrm{a}}$ ordem do rio Uruguai, localizado no extremo oeste do Rio Grande do Sul. As amostragens foram realizadas por meio de quadrats de $5 \mathrm{~m}^{2}$, cinco em cada seção, amostrandose um total de $50 \mathrm{~m}$. Também foram feitas amostragens em um ambiente lêntico, com comunicação intermitente com o Touro Passo, objetivando detectar a existência de transporte de comunidades lênticas para o interior do rio. Os resultados obtidos mostram que, apesar da freqüente oscilação do nível da água, a biocenose do Touro Passo apresenta uma alta fidelidade ecológica e sofre pouca influência de espécies de ambientes lênticos. A composição taxonômica e características de estrutura de comunidades, especialmente as espécies dominantes, refletem, ainda, diferenças ecológicas relacionadas às duas seções amostradas, como a maior complexidade de habitats da estação meandrante. Quanto à fidelidade quantitativa, 60\% das espécies encontradas vivas também foram encontradas mortas e 47,3\% das espécies encontradas mortas também foram encontras vivas em escala de rio. Porém, $72 \%$ dos exemplares coletados mortos são representantes de espécies encontradas vivas. Essa percentagem alta pode estar relacionada à boa correlação entre o ranking de dominância das associações vivas e mortas e, conseqüentemente, as espécies dominantes das tanatocenoses podem ser utilizadas para inferir características ecológicas das biocenoses. Todos os índices analisados variaram muito em escala local (quadrat) e seus valores são mais aproximados aos de outros, registrados em estudos prévios, apenas quando analisados em escala mais ampla (seção, área total).

PALAVRAS-CHAVE. Moluscos límnicos, tafonomia, associações mortas, associações vivas.

According to BeHRENSMEYER et al. (2000), the quantitative fidelity is "... the quantitative faithfulness of the record of morphs, age classes, species richness, species abundance, trophic structure, etc. to the original biological signal". In other words, it is the degree of the similarity between the life assemblage and the potential death assemblage. This "degree of similarity" is governed by an interaction of multiple extrinsic/intrinsic factors, such as (a) the source and rate of shell supply, (b) the vulnerability of skeletal hard parts to post-mortem destruction or modification, and (c) the taphonomic conditions that the bioclasts are exposed in the environment of depositon (Kidwell \& Bosence, 1991). Time-averaging (or temporal-mixing) is another important issue affecting the fidelity of death assemblages (WALKER
\& BAMBACH, 1971). This phenomenon promotes the mixing of multiple non contemporaneous generations of shelly organisms and/or communities. Time-averaged death assemblages can be a product of multiple processes, including (a) the out-of-habitat transport of skeletal remains by storm-induced flows and currents, (b) extensive reworking by waves and currents, (c) intrastratal biological activity, (d) selective destruction of species and/or preferable size-classes, and (e) sea-level fluctuations and rates of sedimentation (Cummins, 1994; Kidwell \& Flessa, 1995; Behrensmeyer et al., 2000; KowALEWSKi et al., 2003).

The vast majority of the studies on compositional fidelity has been conducted in shallow water marine to transitional settings, including estuaries, lagoons, bays 
and continental shelves. These focus primarily on mollusks, especially bivalves (KIDWELL \& BOSENCE, 1991; Cummins, 1994; Kidwell \& Flessa, 1995; Behrensmeyer et al., 2000; KowAlEWSKi et al., 2003). Hence, as highlighted by KowALEWSKI et al. (2003), our view of this issue is biased toward specific taxonomic groups (bivalvocentric) and environments, lacking data for several shelly groups both from marine and continental environments. In spite of that, the data available shown that the live/dead agreement is high (KIDwELL \& BosenCE, 1991; KIDWELL \& FLESSA, 1995) for the marine molluscan assemblages, but the dead/live agreement is variable (high, Kowalewski et al., 2003 or low, Kidwell \& Bosence, 1991; Kidwell \& Flessa, 1995). Results may vary, however, according to the spatial scale employed in the analysis (Cummnis, 1994; Kidwell \& Flessa, 1995; KowALEWSKi et al., 2003). For example, low dead/live agreement is generally shown by assemblages representing limited sampling strategies and encompassing small-scale coverage. Normally, the commonest species with preservable hardparts are the one better represented in the death assemblages, showing good fidelity to the original life assemblages (KIDWELl \& FlesSA, 1995; KidwELl, 2001).

Despite its importance providing essential paleoecological and paleoclimatological information, shelly assemblages from freshwater systems have received far less attention in taphonomic studies than the marine ones. The limited fidelity data available for molluscan assemblages of this system have shown that the live/dead agreement can be high (Cummins, 1994) or low (PIP, 1988). However, these studies are also limited in terms of facies coverage, focusing primarily on lentic settings (PIP, 1988; CoHEN, 1989; CuMmins, 1994). Here again the taphonomic knowledge is biased toward some facies or subenvironments. For typical lotic fluvial environments, where the currents can be an important agent of post-mortem out-of-habitat transportation of shells, only a few studies provided scarse, but important data (e.g., Briggs et al., 1990; WARREN, 1991; Cummins, 1994). These studies suggest that the different types of the molluscan life and death assemblages tend to accumulate in distinct depositional settings (e.g., channel, flood plains, oxbow lakes) and are influenced by several biotic and abiotic agents (see PIP, 1988, for a revision).

The Touro Passo River, a tributary of the Uruguay River basin, in the west of the State of Rio Grande do Sul, Brazil, provides a good opportunity for accessing the quantitative fidelity of fluvial molluscan shelly assemblages. According to Édson Oliveira (pers. comm.), at least three families and six genera of bivalve mollusks are thriving in the river nowadays. Because the low depth of the channel $(\sim 6 \mathrm{~m})$ and the dry seasons, these shells can be easily collected. In addition, several information on the biology and ecology of the southern Brazilian freshwater mollusks are available in the literature (e.g. Veitenheimer \& MAnsur, 1978; Silva \& Thomé, 1981; Lopes-Pitoni et al., 1984; Lanzer \& VeitenheimerMendes, 1985; Mansur \& Garces, 1988; Mansur et al., 1987, 1988, 1991, 1994, 2001, 2003b; PEREIRA et al. 2000a,b, 2001; VeITENHEIMER-MENDEs et al., 1990, 1992; LANZER, 1991, 1996; Oliveira \& Mansur, 2001; Focht \&
VeItenheimer-Mendes, 2001), complemented by studies in adjacent areas of the Uruguay and Argentina (see revision in MARTINEZ \& ROJAS, 2004). Finally, the presence of Cenozoic Touro Passo Formation outcrops along the river's margin, including mollusk-dominated assemblages of Pleistocene/Holocene ages (Bombin, 1976; OliveIRA \& Milder, 1990), can offer valuable data for future comparisons with the fidelity data presented here.

In the context above, the purpose of this contribution is to analyze the quantitative fidelity of the present-day molluscan assemblages that occur in distinct fluvial environments of the Touro Passo River in order to verify: (a) the ecological fidelity (sensu DAJOz, 1978) of the biocoenoses; (b) the paleoecological fidelity by means of live/dead and dead/live comparisons among the biocoenoses and thanatocoenoses found in channels with distinct morphologies and bottom types; and (c) the percentage of dead individuals from species found alive.

\section{MATERIAL AND METHODS}

The Touro Passo River is a tributary of the left margin of the Uruguay River basin, located in Uruguaiana County, State of Rio Grande do Sul (Fig. 1). Its springs are located 140 meters above sea-level, changing to $60 \mathrm{~m}$ in the mid course and to $40 \mathrm{~m}$ in the river's mouth (BOMBIN, 1976). Floodings are frequent and are, in part, caused by floods of the Uruguay River or are a consequence of torrential rains. Also, these may be caused by the low capacity of the hydrological system, with the river overruning all the flood plains (BomBin, 1976).

The course of the Touro Passo River shows a varied of morphologies, including straight and meandering to braided sectors. Hence, the river includes several fluvial subenvironments, supporting different types of freshwater communities. The channels have a great range of depth and their margins are covered by riparian vegetation (Bombin, 1976). Sandy bottoms predominate, and aquatic plants are rare (Tab. I).

In the studied sectors, the Touro Passo River is a forth-order river (see STRAHLER \& STRAHLER, 1989), which supposedly favour the deposition of great amount of live materials and dead skeletal remains (see Christofoletti, 1980).

The climate of the region is subtropical, type Cfa II2a (Köppen's classification, MoRENO, 1961). The mean annual precipitation value is $1350 \mathrm{~mm}$, with rains equally distributed during the year. The mean annual temperature is $19^{\circ} \mathrm{C}$ (maximum averages of $26^{\circ} \mathrm{C}$, in January, and minimum averages of $12^{\circ} \mathrm{C}$, in July), with the humidity reaching $70 \%$ (SARTORI, 2003).

The area is represented by the grasslands (locally named Campanha), with stony fields and shallow soils (PORTO, 2002). The vegetation includes deciduous woody, generally thorny, including arboreal/shrub species, as the "espinilho" [Acacia farnesiana (L.)] (Fabaceae), and wild and succulent plants, showing grassy/herbaceous coverings, typical of subtropical areas (BomBIN, 1976; LeITE, 2002; PORTO, 2002).

Samplings were carried out in two different river sectors, with distinct channel morphologies: straight (SS) 
and meandering-sectors (MS), both located in the midcourse of the Touro Passo River (Fig. 1). We also sampled a partially dammed channel. There an artificial dam was built to supply water to local agricultural activities, during the dry seasons. Thus, during the water-deficienty periods the channel looses connection with the main river channel, acting as an abandoned meander channel (AMS) (Fig. 1).

The collecting stations in the SS include two sites, both with low sinuosity. Although sandy bottoms predominate, fine-grained (muddy) compacted substrates are also present (Édson Oliveira, pers. comm.). In some sites, the margins show steep slope and the channel reaches nearly $1.60 \mathrm{~m}$ of depth. The current velocities range from moderate to strong with continuous flow (Tab. I).

The collecting station in the MS is located in the meandering to braided sector of the river (BOMBIN, 1976) (Fig. 1). Small and shallow channels, some with braided pattern, occur in the alluvial island that separates the main channel from the secondary one (Fig. 1). The island is characterized by the presence of riparian vegetation, offering little shadowing for the river's margins. Physical and hydrological properties of each channel are very distinct (Tab. I).

Sampling in the MS included five substations for each station (Fig. 1). The molluscan fauna of the AMS was sampled to record possible out-of-habitat species that were transported during floods. The vegetation of the AMS is characterized by riparian coverage and by the presence of the aquatic macrophyte Nymphoides indica (L.) O. Kuntze (Menyanthaceae). The site is characterized by low luminosity, less than $60 \mathrm{~cm}$ of depth, and organic-rich bottoms.
The biocoenoses (life assemblages) and thanatocoenoses (death assemblages) were sampled in February (dry period) and May (flood period) of 2003, and in April (dry period) of 2004. In the MS, samplings were conducted only during the dry season. During the May floodings the water level rises and associated with the strong currents made impossible the sampling of the MS bottoms, due to the steep margins of this sector. It is important to emphasize that in the SS sector the oscilation of the water level is smaller than in the MS, and the shells were captured at the same sites during the flood and dry periods.

In each substation (SS 01 to 05 and MS 01 to 05 ), the mollusks were collected using quadrats with sampling area of $5 \mathrm{~m}^{2}$. This area is adequate to the low abundance of freshwater mollusks, such as Unionacea (Cummins, 1994). Consequently, an area of $25 \mathrm{~m}^{2}$ was sampled for each station. In the AMS, samplings included three quadrats only.

The mollusks were collected with sieves (mesh of 1 $\mathrm{mm}$ ) especially in the river's margins, not overstepping 1 $\mathrm{m}$ of depth. In the AMS, the macrophytes were removed and examined individually, and the mollusks were handly collected. In the substation MS 02, adjacent to a fossiliferous outcrop of the Touro Passo Formation, the fossil mollusks, whenever identified, were removed of the sampling.

Live-collected specimens were preserved in $80 \%$ ethyl alcohol, and the dead ones stored in plastic bags. The specimens (shell fragments included), were identified to species level, whenever possible.

Taxonomic identification was conducted using the extensive malacological literature available and with help

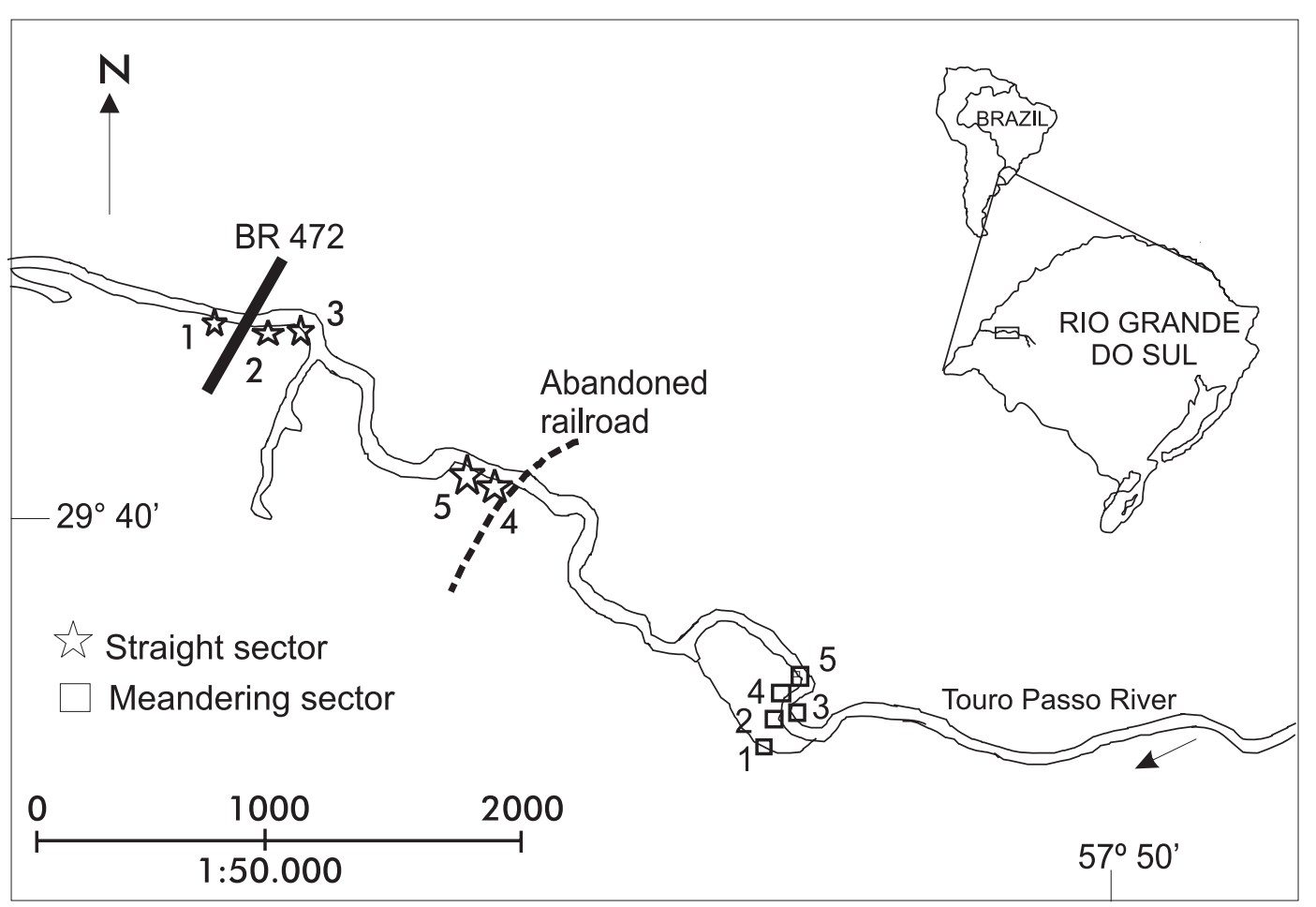

Fig. 1. Studied substations in the stations of the straight and meandering sectors, located in the middle course of the Touro Passo River, Uruguaiana, RS. 
of specialists. The studied mollusks were deposited in the "Coleção de Invertebrados, Setor de Zoologia, Departamento de Biologia, Universidade Federal de Santa Maria (UFSM)".

For each mollusk assemblage, analyses included (a) the number (n) of individuals, (b) the relative frequency $(\%)$, and (c) the numeric dominance (the numerically dominant species in each site sampled).

To determine the number of bivalves in the death assemblages, for each station, the disarticulated matching valves (right/left) were considered as one individual. According to KOWALEWSKI et al. (2003) "although all valves (including fragments) may represent unique individuals when the sampling domain is large, some correction for disarticulated elements still needs to be applied when bivalved organisms are analyzed together with univalved organisms. This is because univalved specimens are half as likely to be sampled as bivalved organisms". Consequently, the number of disarticulated valves, with no matching valves, was corrected by a factor of 0.5 (see KowALEWSKI et al., 2003 for this methodological procedure). Because shell fragments were extremely rare, exhaustive analyses were not employed (KowALEWSKI et al., 2003).
Species diversity and richness were calculated for the evaluation and comparison of diversity of each studied station. The richness (S) was measured, according to the number of different species in each station. The diversity index applied was the ShannonWiener $\left(H^{\prime}=-\Sigma p_{i} \cdot \log _{e} p_{i}\right)$ index, where $p_{i}$ is the proportion of individuals found in the $n$ species (MAgurRan, 1988).

The analysis of the ecological fidelity of the biocoenoses (i.e., the intensity in which each species is associated with the biocoenoses) followed the Dajoz's classification (DAJOz, 1978). According to this, the following species are present: (a) characteristic species (eucoen) - exclusively occurs in one biocoenosis or is commonly abundant in certain associations; (b) preferential species (tychocoen) - occurs in several biocoenoses, but showing preference for one of them; (c) strange (xenoecic) - accidentally occurs in the biocoenoses and, (d) indifferent species - indifferently occurs in several biocoenoses.

The Sorensen index of similarity was used to compare the species composition of the life and death assemblages, in terms of the number of species present

Table I. Location and characterization of the substations of the straight (SS) and meandering (MS) sectors in the middle course of the Touro Passo River (substratum granulometry according to Édson Oliveira, PUC/RS, pers. comm.).

\begin{tabular}{lll}
\hline Substations & Location & Characterization
\end{tabular}

SS01 $3 \mathrm{~m}$ west of the bridge on road BR 472 . Substrate constituted especially by silt and subordinately fine and coarse
sand and clay, no shadowing, flat margin, depth of $20 \mathrm{~cm}$ (dry season), no aquatic plants.

SS02 $3 \mathrm{~m}$ east of the bridge on road BR 472

Substrate constituted especially by silt and subordinately fine and coarse sand and clay, little shadowed due to the riparian vegetation, no aquatic plants, depth inferior of $20 \mathrm{~cm}$, strong current (dry season).

SS03 $5 \mathrm{~m}$ east of the bridge on road BR 472 Substrate constituted especially by silt and subordinately fine and coarse sand and clay, little shadowed due to the riparian vegetation, no aquatic plants, depth of $20 \mathrm{~cm}$ (dry season) and margin with slope of $30^{\circ}$.

SS04 $4 \mathrm{~m}$ west on of the abandoned railroad Substrate constituted by silt and coarse sand, with presence of clay in the margins, no shadowing, presence of grass vegetation, margin with slope of $30^{\circ}$ and depth about $1.5 \mathrm{~m}$ (flood season).

SS05 $6 \mathrm{~m}$ west of the "Ponte Velha", the old bridge on the abandoned railroad.

MS01 Located in the secondary channel of the river. Substrate constituted by silt and coarse sand, with presence of clay in the margins, with riparian and grass vegetation, no aquatic plants, margin with slope of $45^{\circ}$ and depth of about $1.5 \mathrm{~m}$ (flood season). Substrate constituted especially by silt and clay, and locally by fine and coarse sand, riparian vegetation in the left margin, no shadowing, intermittent water flow, generally weak and shallow current, delineated by a terrace with $3 \mathrm{~m}$ height in the left margin.

Substrate constituted especially by coarse sand, riparian vegetation in the left margin, little shadowed, weak current, depth of $1 \mathrm{~m}$, and slope of $20^{\circ}$.

Substrate constituted especially by pebbles and cobbles, with riparian vegetation in the margins, no shadowing, weak current, depth of $1 \mathrm{~m}$ and slope of $20^{\circ}$.

Substrate constituted by coarse sand, pebbles and cobbles, riparian vegetation in the margins, no shadowing, weak current, depth of $1.5 \mathrm{~m}$ and flat margin.

Substrate constituted especially by coarse sand and subordinately by fine sand, silt and locally compacted clay, no shadowing, weak current and $1 \mathrm{~m}$ of depth. 
and the number of species in common, according to the formula: $\mathrm{S}=2 \mathrm{C} /(\mathrm{A}+\mathrm{B})$ where $\mathrm{S}=$ index of similarity, $\mathrm{A}=$ number of species in death assemblage, $\mathrm{B}=$ number of species in life assemblages, and $\mathrm{C}=$ number of species common to both life and death assemblage (ODuM, 1988).

The quantitative fidelity was analyzed considering (see also Kidwell \& Bosence, 1991): (a) the live/dead agreement or the percentage of shelly species found live and also dead in a given site $\left(\mathrm{N}_{\mathrm{S}} \times 100 / \mathrm{N}_{\mathrm{L}}+\mathrm{N}_{\mathrm{S}}\right)$; (b) the dead/live agreement or the percentage of species found dead and also found live $\left(\mathrm{N}_{\mathrm{S}} \times 100 / \mathrm{N}_{\mathrm{D}}+\mathrm{N}_{\mathrm{S}}\right)$; and (c) the percentage of dead individuals from species found alive [(dead individuals of $\left.\mathrm{N}_{\mathrm{S}} \times 100\right) /\left(\right.$ dead individuals of $\mathrm{N}_{\mathrm{D}}+$ $\mathrm{N}_{\mathrm{S}}$ )], where $\left(\mathrm{N}_{\mathrm{L}}\right)$ is the number of species found live only, $\left(\mathrm{N}_{\mathrm{D}}\right)$ is the number of species found dead only and $\left(\mathrm{N}_{\mathrm{S}}\right)$ is the number of species found both live and dead.
The Spearman Rank correlation (rs) test was applied to compare the ranking order of the most abundant species of the life and death assemblages. Finally, all analyses were performed at the station-level (sectors SS and MS) and also pooling the data to the whole river (site-scale or river-scale) (except the Shannon-Wiener diversity index). The Mann-Whitney test was used to analyze the differences between stations, using $5 \%$ of significance $(\mathrm{p}<0.05)$.

\section{RESULTS AND DISCUSSION}

Biocoenoses. A total of 1,226 specimens belonging to 12 mollusk (gastropod and bivalve) species were recorded in the studied biocoenoses (Tab. II). The bivalves were represented by 136 individuals, belonging to: Diplodon

Table II. Number of specimens (n), frequency (\%) of the species, richness (S) and diversity (H') of the molluscan life assemblages found in substations of the straight (SS) and meandering (MS) sectors of the middle course of the Touro Passo River, Uruguaiana, RS. The value of Shannon-Wiener (H') index was not obtained for the substations SS1, SSR2 and MS3, as they show only one species.

\begin{tabular}{|c|c|c|c|c|c|c|c|c|c|c|c|c|c|}
\hline $\begin{array}{l}\text { Substations/ } \\
\text { Species }\end{array}$ & $\begin{array}{c}\text { SS01 } \\
\text { n } \\
(\%)\end{array}$ & $\begin{array}{c}\mathrm{SS} 02 \\
\mathrm{n} \\
(\%)\end{array}$ & $\begin{array}{c}\text { SS03 } \\
\mathrm{n} \\
(\%)\end{array}$ & $\begin{array}{c}\text { SS04 } \\
\mathrm{n} \\
(\%)\end{array}$ & $\begin{array}{c}\text { SS05 } \\
\text { n } \\
(\%)\end{array}$ & $\begin{array}{c}\text { SS } \\
\text { Total }\end{array}$ & $\begin{array}{c}\text { MS01 } \\
\text { n } \\
(\%)\end{array}$ & $\begin{array}{c}\text { MS02 } \\
\mathrm{n} \\
(\%)\end{array}$ & $\begin{array}{c}\mathrm{MS} 03 \\
\mathrm{n} \\
(\%)\end{array}$ & $\begin{array}{c}\text { MS04 } \\
\mathrm{n} \\
(\%)\end{array}$ & $\begin{array}{c}\text { MS05 } \\
\text { n } \\
(\%)\end{array}$ & $\begin{array}{c}\text { MS } \\
\text { Total }\end{array}$ & $\begin{array}{c}\text { Total } \\
\mathrm{n} \\
(\%)\end{array}$ \\
\hline \multicolumn{14}{|l|}{ GASTROPODA } \\
\hline P. canaliculata & 0 & 0 & $\begin{array}{c}1 \\
(1.2)\end{array}$ & $\begin{array}{c}1 \\
(50)\end{array}$ & $\begin{array}{c}3 \\
(60)\end{array}$ & $\begin{array}{c}5 \\
(2.6)\end{array}$ & 0 & 0 & 0 & 0 & 0 & 0 & $\begin{array}{c}5 \\
(0.41)\end{array}$ \\
\hline$P$. aff. orbigny & $\begin{array}{c}51 \\
(100)\end{array}$ & $\begin{array}{c}53 \\
(100)\end{array}$ & $\begin{array}{c}80 \\
(98.8)\end{array}$ & 0 & 0 & $\begin{array}{c}184 \\
(95.8)\end{array}$ & 0 & $\begin{array}{c}54 \\
(41.5)\end{array}$ & 0 & $\begin{array}{c}47 \\
(43.5)\end{array}$ & $\begin{array}{c}330 \\
(46.4)\end{array}$ & $\begin{array}{c}431 \\
(41.6)\end{array}$ & $\begin{array}{c}615 \\
(50.2)\end{array}$ \\
\hline Potamolithus sp. & 0 & 0 & 0 & 0 & 0 & 0 & $\begin{array}{c}2 \\
(10)\end{array}$ & $\begin{array}{c}9 \\
(6.9)\end{array}$ & $\begin{array}{c}64 \\
(100)\end{array}$ & $\begin{array}{c}20 \\
(18.5)\end{array}$ & $\begin{array}{c}372 \\
(52.2)\end{array}$ & $\begin{array}{c}467 \\
(45.2)\end{array}$ & $\begin{array}{c}467 \\
(38.1)\end{array}$ \\
\hline Biomphalaria sp. & 0 & 0 & 0 & $\begin{array}{c}1 \\
(50)\end{array}$ & $\begin{array}{c}1 \\
(20)\end{array}$ & $\begin{array}{c}2 \\
(1.0)\end{array}$ & $\begin{array}{c}1 \\
(5)\end{array}$ & 0 & 0 & 0 & 0 & $\begin{array}{c}1 \\
(0.09)\end{array}$ & $\begin{array}{c}3 \\
(0.25)\end{array}$ \\
\hline Subtotal (n) & 51 & 53 & 81 & 2 & 4 & 191 & 3 & 63 & 64 & 67 & 702 & 899 & 1,090 \\
\hline Subtotal (S) & 1 & 1 & 2 & 2 & 2 & 3 & 2 & 2 & 1 & 2 & 2 & 3 & 4 \\
\hline $\begin{array}{l}\text { BIVALVIA } \\
\text { D. delodontus } \\
\text { wymani }\end{array}$ & 0 & 0 & 0 & 0 & 0 & 0 & $\begin{array}{c}3 \\
(15)\end{array}$ & $\begin{array}{c}1 \\
(0.8)\end{array}$ & 0 & 0 & 0 & $\begin{array}{c}4 \\
(0.4)\end{array}$ & $\begin{array}{c}4 \\
(0.3)\end{array}$ \\
\hline Diplodon sp. & 0 & 0 & 0 & 0 & 0 & 0 & 0 & 0 & 0 & $\begin{array}{c}3 \\
(2.8)\end{array}$ & $\begin{array}{c}1 \\
(0.1)\end{array}$ & $\begin{array}{c}4 \\
(0.4)\end{array}$ & $\begin{array}{c}4 \\
(0.3)\end{array}$ \\
\hline $\begin{array}{l}\text { A. trapesialis } \\
\text { forbesianus }\end{array}$ & 0 & 0 & 0 & 0 & 0 & 0 & 0 & $\begin{array}{c}1 \\
(0.8)\end{array}$ & 0 & 0 & 0 & $\begin{array}{c}1 \\
(0.09)\end{array}$ & $\begin{array}{c}1 \\
(0.09)\end{array}$ \\
\hline C. fluminea & 0 & 0 & 0 & 0 & 0 & 0 & $\begin{array}{c}5 \\
(25)\end{array}$ & $\begin{array}{c}3 \\
(2.3)\end{array}$ & 0 & $\begin{array}{c}2 \\
(1.9)\end{array}$ & $\begin{array}{c}2 \\
(0.3)\end{array}$ & $\begin{array}{c}12 \\
(1.16)\end{array}$ & $\begin{array}{c}12 \\
(1.0)\end{array}$ \\
\hline C. largillierti & 0 & 0 & 0 & 0 & 0 & 0 & 0 & $\begin{array}{c}62 \\
(47.7)\end{array}$ & 0 & $\begin{array}{c}34 \\
(31.5)\end{array}$ & $\begin{array}{c}7 \\
(1.0)\end{array}$ & $\begin{array}{c}103 \\
(9.96)\end{array}$ & $\begin{array}{l}103 \\
(8.4)\end{array}$ \\
\hline E. klappenbachi & 0 & 0 & 0 & 0 & $\begin{array}{c}1 \\
(20)\end{array}$ & $\begin{array}{c}1 \\
(0.6)\end{array}$ & 0 & 0 & 0 & $\begin{array}{c}1 \\
(0.9)\end{array}$ & 0 & $\begin{array}{c}1 \\
(0.09)\end{array}$ & $\begin{array}{c}2 \\
(0.16)\end{array}$ \\
\hline P. punctiferum & 0 & 0 & 0 & 0 & 0 & 0 & 0 & 0 & 0 & $\begin{array}{c}1 \\
(0.9)\end{array}$ & 0 & $\begin{array}{c}1 \\
(0.09)\end{array}$ & $\begin{array}{c}1 \\
(0.09)\end{array}$ \\
\hline P. sterkianum & 0 & 0 & 0 & 0 & 0 & 0 & $\begin{array}{c}9 \\
(45)\end{array}$ & 0 & 0 & 0 & 0 & $\begin{array}{c}9 \\
(0.9)\end{array}$ & $\begin{array}{c}9 \\
(0.7)\end{array}$ \\
\hline Subtotal (n) & 0 & 0 & 0 & 0 & 1 & 1 & 17 & 67 & 0 & 41 & 10 & 135 & 136 \\
\hline Subtotal (S) & 0 & 0 & 0 & 0 & 1 & 1 & 3 & 4 & 0 & 5 & 3 & 8 & 8 \\
\hline TOTAL (n) & 51 & 53 & 81 & 2 & 5 & 192 & 20 & 130 & 64 & 108 & 712 & 1,034 & 1,226 \\
\hline RICHNESS (S) & 1 & 1 & 2 & 2 & 3 & 4 & 5 & 6 & 1 & 7 & 5 & 11 & 12 \\
\hline $\mathrm{H}^{\prime}$ & - & - & 0.07 & 0.69 & 0.95 & 0.21 & 1.37 & 1.06 & - & 1.30 & 0.77 & 1.12 & 1.10 \\
\hline
\end{tabular}


delodontus wymani (Lea, 1860) (Figs. 6,7), Diplodon sp., Anodontites trapesialis forbesianus (Lamarck, 1819) (Figs. 10,11), Corbicula fluminea (Müller, 1774), C. largillierti (Philippi, 1844) (Figs. 18,19), Eupera klappenbachi Mansur \& Veitenheimer, 1975 (Figs. 16,17), Pisidium punctiferum (Guppy, 1867) and P. sterkianum Pilsbry, 1897 (Figs. 14,15). The gastropods encompassed 1,090 specimens, attributed to Pomacea canaliculata (Lamarck, 1801) (Fig. 4), Potamolithus aff. orbigny Pilsbry, 1896 (Fig. 3), Potamolithus sp. and Biomphalaria sp. (Fig. 5).

Pooling the data, the dominant species (\%) in the studied sectors of the Touro Passo River are the gastropods Potamolithus aff. orbigny and Potamolithus sp. (Tab. II). Among the bivalves, $C$. largillierti was the dominant species. In the different river sectors, the richness and the number of individuals were higher in the MS biocoenoses, but this difference was not significant $(\mathrm{p}=0.076)$. In the AMS site, the following species and number of individuals were assigned: Biomphalaria sp. $(16.6 \%, \mathrm{n}=42)$, Gundlachia moricandi (Orbigny, 1837) (78.2\%, n=197) (Fig. 2) and P. punctiferum $(5.1 \%, \mathrm{n}=13)$. The Shannon-Wiener diversity index was higher for the MS assemblages (Tab. II).

Based on previous studies (PAROdiz \& Hennings, 1965; BonetTo et al., 1982; Di Persia \& OlazARri, 1986; Mansur \& Garces, 1988; Ituarte, 1984, 1994; Veitenheimer-Mendes et al., 1992; Duarte \& DiefEnBaCh, 1994; LANZER, 1996; MANSUR et al., 1988, 1991, 1994, 2001; Pereira et al., 2000a, 2001; Focht \& VeitenheimerMendes, 2001; Oliveira \& Mansur, 2001; Martinez \&
RoJAs, 2004), the ecological fidelity of the species recorded is as follows: (a) characteristics, $C$. fluminea and $C$. largillierti; (b) preferential, $P$. aff. orbigny, Potamolithus sp., D. delodontus wymani, Diplodon sp., A. trapesialis forbesianus and E. klappenbachi; (c) strange, Biomphalaria sp., and (d) indifferents, $P$. canaliculata, $P$. punctiferum and $P$. sterkianum. In the assemblages of AMS, G. moricandi and Biomphalaria sp. are characteristics, and P. punctiferum, indifferent.

Thanatocoenoses. A total of 311 specimens, belonging to 13 species of mollusks were recorded in the studied thanatocoenoses (Tab. III). The bivalves totalled 90 individuals, and were represented by $D$. delodontus wymani (Figs. 6, 7), Diplodon parallelopipedon (Lea, 1834) (Figs. 8, 9), Mycetopoda siliquosa (Spix, 1827) (Figs. 12, 13), C. fluminea, C. largillierti (Figs. 18, 19), Neocorbicula limosa (Maton, 1811), E. klappenbachi (Figs. 16, 17) and $P$. sterkianum (Figs. 14, 15). Gastropods (n=221) were atributted to five species, including: P. canaliculata (Fig. 4), Heleobia aff. bertoniana Pilsbry, 1911, P. aff. orbigny (Fig. 3), Potamolithus sp. and Biomphalaria sp. (Fig. 5). Pooling the data, the dominant species in the thanatocoenoses are $P$. aff. orbigny (Fig. 3), Potamolithus sp. and C. largillierti (Figs. 18, 19). The highest richness and abundance were recorded in the meandering-sector. However, this result was not significantly different $(\mathrm{p}=0.076)$.

Thanatocoenoses $x$ biocoenoses. Shells in death assemblages are less abundant than in the life
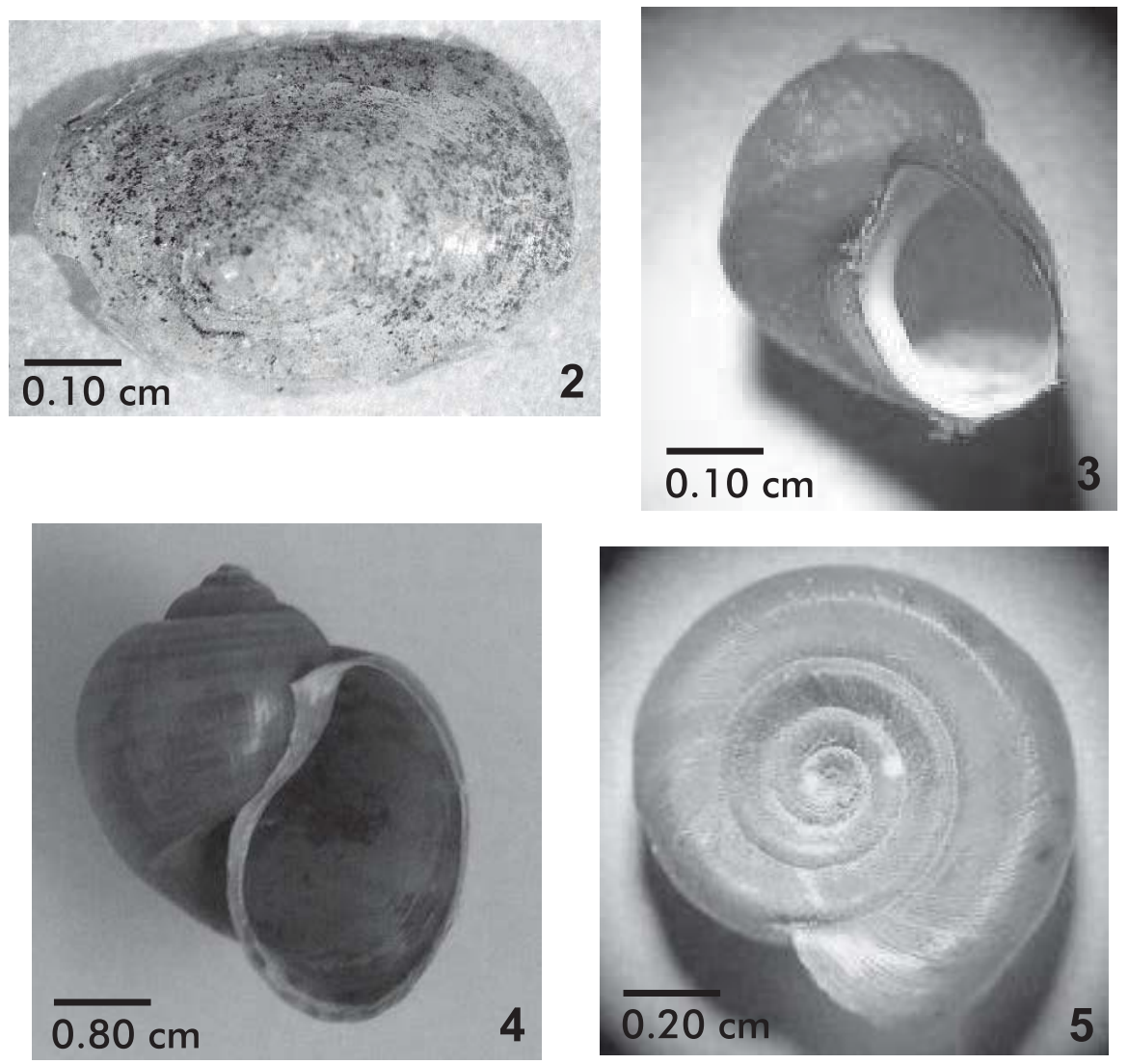

Figs. 2-5. Gastropods of the Touro Passo River. 2, shell of Gundlachia moricandi, dorsal view; 3, shell of Potamolithus aff. orbigny, ventral view; 4, shell of Pomacea canaliculata, ventral view; 5, shell of Biomphalaria sp., dorsal view. 
assemblages, both at station-scale and river-scale (RS). However, the differences were not significantly different (SS, $\mathrm{p}=0.530$; MS, $\mathrm{p}=0.175 ; \mathrm{RS}, \mathrm{p}=0.140$, respectively). The total richness for the river's death assemblage $(\mathrm{S}=13)$ was similar to the total richness of the life assemblage $(\mathrm{S}=12)$, and all the gastropod species in the thanatocoenoses were also assigned in the biocoenoses. Only three species of bivalves (A. trapesialis forbesianus, Diplodon sp. and $P$. punctiferum) found in the biocoenoses were not recorded in the thanatocoenoses (Tabs. II, III).

The rank orders of the dominant species of the thanatocoenoses were significantly and positively correlated with those of the biocoenoses. The correlation was good at river-scale ( $\mathrm{rs}=0.56)$ and for the MS assemblages ( $\mathrm{rs}=0.59)$, but very low for the SS assemblages ( $\mathrm{rs}=0.34$ ).

The live/dead agreement (Tab. IV) in the meandering-sector was significantly higher $(73 \%$, $\mathrm{p}=0.035)$ than in the straight-sector $(50 \%)$ (Tabs. II, III). Pooling the data, the index of similarity for the Touro Passo River assemblages reaches 72 (Tab. IV). At riverscale, live/dead (F1) agreement was $60 \%$, and the dead/ live agreement (F2) was $47 \%$. Despite of that, it should be noted that $72.3 \%$ of the dead specimens were represented in the biocoenoses (F3) (Tab. IV).

Whenever the live/dead agreement is analyzed at station-scale, $60 \%$ of the species found alive were also found dead in the SS. On the other hand, the dead/live agreement reaches only $30 \%$ (Tab. IV), but $67.7 \%$ of the

Table III. Number of specimens (n), frequency (\%) of the species, richness (S) and diversity (H') of the molluscan death assemblages found in the substations of the straight (SS) and meandering (MS) sectors in the middle course of the Touro Passo River, Uruguaiana, RS (* values decimals were elevated to number superior).

\begin{tabular}{|c|c|c|c|c|c|c|c|c|c|c|c|c|c|}
\hline $\begin{array}{l}\text { Substations/ } \\
\text { Species }\end{array}$ & $\begin{array}{c}\text { SS01 } \\
\text { n } \\
(\%)\end{array}$ & $\begin{array}{c}\mathrm{SS} 02 \\
\mathrm{n} \\
(\%)\end{array}$ & $\begin{array}{c}\text { SS03 } \\
\text { n } \\
(\%)\end{array}$ & $\begin{array}{c}\text { SS04 } \\
\mathrm{n} \\
(\%) \\
\end{array}$ & $\begin{array}{c}\text { SS05 } \\
\mathrm{n} \\
(\%)\end{array}$ & $\begin{array}{c}\text { SS } \\
\text { Total }\end{array}$ & $\begin{array}{c}\text { MS01 } \\
\text { n } \\
(\%)\end{array}$ & $\begin{array}{c}\text { MS02 } \\
\text { n } \\
(\%)\end{array}$ & $\begin{array}{c}\text { MS03 } \\
\text { n } \\
(\%)\end{array}$ & $\begin{array}{c}\text { MS04 } \\
\text { n } \\
(\%)\end{array}$ & $\begin{array}{c}\text { MS05 } \\
\text { n } \\
(\%)\end{array}$ & $\begin{array}{c}\text { MS } \\
\text { Total }\end{array}$ & $\begin{array}{c}\text { Total } \\
\mathrm{n} \\
(\%)\end{array}$ \\
\hline \multicolumn{14}{|l|}{ GASTROPODA } \\
\hline P. canaliculata & $\begin{array}{c}1 \\
(3.9)\end{array}$ & $\begin{array}{c}2 \\
(5.4)\end{array}$ & 0 & $\begin{array}{c}2 \\
(18.2)\end{array}$ & $\begin{array}{c}5 \\
(22.8)\end{array}$ & $\begin{array}{c}10 \\
(9.9)\end{array}$ & $\begin{array}{c}1 \\
(2.5)\end{array}$ & 0 & 0 & 0 & 0 & $\begin{array}{c}1 \\
(0.5)\end{array}$ & $\begin{array}{c}11 \\
(3.54)\end{array}$ \\
\hline $\begin{array}{l}\text { Heleobia aff. } \\
\text { bertoniana }\end{array}$ & 0 & 0 & 0 & 0 & 0 & 0 & $\begin{array}{c}3 \\
(7.5)\end{array}$ & 0 & 0 & $\begin{array}{c}1 \\
(1.26)\end{array}$ & $\begin{array}{c}1 \\
(3.3)\end{array}$ & $\begin{array}{c}5 \\
(2.4)\end{array}$ & $\begin{array}{c}5 \\
(1.61)\end{array}$ \\
\hline P. aff. orbigny & $\begin{array}{c}11 \\
(42.3)\end{array}$ & $\begin{array}{c}13 \\
(35.1)\end{array}$ & $\begin{array}{c}4 \\
(80)\end{array}$ & 0 & $\begin{array}{c}1 \\
(4.5)\end{array}$ & $\begin{array}{c}29 \\
(28.7)\end{array}$ & 0 & $\begin{array}{c}12 \\
(33.8)\end{array}$ & 0 & $\begin{array}{c}33 \\
(41.5)\end{array}$ & $\begin{array}{c}12 \\
(40)\end{array}$ & $\begin{array}{c}57 \\
(27.1)\end{array}$ & $\begin{array}{c}86 \\
(27.6)\end{array}$ \\
\hline Potamolithus sp. & 0 & 0 & 0 & 0 & 0 & 0 & $\begin{array}{c}22 \\
(55)\end{array}$ & $\begin{array}{c}5 \\
(14.1)\end{array}$ & $\begin{array}{c}23 \\
(92)\end{array}$ & $\begin{array}{c}28 \\
(35.2)\end{array}$ & $\begin{array}{c}11 \\
(36.7)\end{array}$ & $\begin{array}{c}89 \\
(42.4)\end{array}$ & $\begin{array}{c}89 \\
(28.6)\end{array}$ \\
\hline Biomphalaria sp. & $\begin{array}{c}3 \\
(11.5)\end{array}$ & $\begin{array}{c}3 \\
(8.1)\end{array}$ & 0 & $\begin{array}{c}5 \\
(45.4)\end{array}$ & $\begin{array}{c}2 \\
(9.1)\end{array}$ & $\begin{array}{c}13 \\
(12.8)\end{array}$ & $\begin{array}{c}6 \\
(15)\end{array}$ & 0 & $\begin{array}{c}2 \\
(8)\end{array}$ & $\begin{array}{c}7 \\
(8.8)\end{array}$ & $\begin{array}{c}2 \\
(6.7)\end{array}$ & $\begin{array}{c}17 \\
(8.1)\end{array}$ & $\begin{array}{c}30 \\
(9.65)\end{array}$ \\
\hline Subtotal (n) & 15 & 18 & 4 & 7 & 8 & 52 & 32 & 17 & 25 & 69 & 26 & 169 & 221 \\
\hline Subtotal (S) & 3 & 3 & 1 & 2 & 3 & 3 & 4 & 2 & 2 & 4 & 4 & 5 & 5 \\
\hline BIVALVIA & & & & & & & & & & & & & \\
\hline $\begin{array}{l}\text { D. delodontus } \\
\text { wymani }\end{array}$ & 0 & 0 & 0 & 0 & $\begin{array}{c}1 \\
(4.5)\end{array}$ & $\begin{array}{c}1 \\
(1.0)\end{array}$ & $\begin{array}{c}1 \\
(2.5)\end{array}$ & $\begin{array}{c}1 \\
(2.8)\end{array}$ & 0 & $\begin{array}{c}0.5 \\
(0.63)\end{array}$ & 0 & $\begin{array}{c}2.5 \\
(1.2)\end{array}$ & $\begin{array}{c}3.5 \\
(1.12)\end{array}$ \\
\hline $\begin{array}{l}\text { D. } \\
\text { parallelopipedon }\end{array}$ & $\begin{array}{c}3 \\
(11.5)\end{array}$ & $\begin{array}{c}1 \\
(2.7)\end{array}$ & 0 & 0 & 0 & $\begin{array}{c}4 \\
(4.0)\end{array}$ & 0 & 0 & 0 & 0 & 0 & 0 & $\begin{array}{c}4 \\
(1.3)\end{array}$ \\
\hline M. siliquosa & 0 & 0 & 0 & 0 & 0 & 0 & 0 & 0 & 0 & $\begin{array}{c}2 \\
(2.52)\end{array}$ & 0 & $\begin{array}{c}2 \\
(0.9)\end{array}$ & $\begin{array}{c}2 \\
(0.65)\end{array}$ \\
\hline C. fluminea & $\begin{array}{c}3 \\
(11.5)\end{array}$ & $\begin{array}{c}3 \\
(8.1)\end{array}$ & 0 & 0 & 0 & $\begin{array}{c}6 \\
(5.9)\end{array}$ & $\begin{array}{c}3 \\
(7.5)\end{array}$ & $\begin{array}{c}1.5 \\
(4.2)\end{array}$ & 0 & $\begin{array}{c}0.5 \\
(0.63)\end{array}$ & 0 & $\begin{array}{c}5 \\
(2.4)\end{array}$ & $\begin{array}{c}11 \\
(3.54)\end{array}$ \\
\hline C. largillierti & $\begin{array}{c}5 \\
(19.3)\end{array}$ & $\begin{array}{c}15 \\
(40.6)\end{array}$ & 0 & $\begin{array}{c}1 \\
(9.1)\end{array}$ & $\begin{array}{c}13 \\
(59.1)\end{array}$ & $\begin{array}{c}34 \\
(33.7)\end{array}$ & $\begin{array}{c}1 \\
(2.5)\end{array}$ & $\begin{array}{c}16 \\
(45.1)\end{array}$ & 0 & $\begin{array}{c}6.5 \\
(8.2)\end{array}$ & $\begin{array}{c}4 \\
(13.3)\end{array}$ & $\begin{array}{c}27.3 \\
(13.1)\end{array}$ & $\begin{array}{c}61.5 \\
(19.8)\end{array}$ \\
\hline N. limosa & 0 & 0 & $\begin{array}{c}1 \\
(20)\end{array}$ & $\begin{array}{c}3 \\
(27.3)\end{array}$ & 0 & $\begin{array}{c}4 \\
(4.0)\end{array}$ & 0 & 0 & 0 & 0 & 0 & 0 & $\begin{array}{c}4 \\
(1.3)\end{array}$ \\
\hline E. klappenbachi & 0 & 0 & 0 & 0 & 0 & 0 & 0 & 0 & 0 & $\begin{array}{c}1 \\
(1.26)\end{array}$ & 0 & $\begin{array}{c}1 \\
(0.5)\end{array}$ & $\begin{array}{c}1 \\
(0.32)\end{array}$ \\
\hline P. sterkianum & 0 & 0 & 0 & 0 & 0 & 0 & $\begin{array}{c}3 \\
(7.5)\end{array}$ & 0 & 0 & 0 & 0 & $\begin{array}{c}3 \\
(1.4)\end{array}$ & $\begin{array}{c}3 \\
(0.97)\end{array}$ \\
\hline Subtotal (n) & 11 & 19 & 1 & 4 & 14 & 49 & 8 & 18.5 & 0 & 10.5 & 4 & 41 & 90 \\
\hline Subtotal (S) & 3 & 3 & 1 & 2 & 2 & 5 & 4 & 3 & 0 & 5 & 1 & 6 & 8 \\
\hline TOTAL (n) & 26 & 37 & 5 & 11 & 22 & 101 & 40 & 35.5 & 25 & 79.5 & 30 & 210 & 311 \\
\hline RICHNESS (S) & 6 & 6 & 2 & 4 & 5 & 8 & 8 & 5 & 2 & 9 & 5 & 11 & 13 \\
\hline $\mathrm{H}^{\prime} *$ & 1.55 & 1.40 & 0.50 & 1.24 & 1.15 & 1.69 & 1.47 & 1.26 & 0.28 & 1.46 & 1.30 & 1.58 & 1.82 \\
\hline
\end{tabular}


dead specimens have living representatives (F3) (Tab. IV). In the MS site, $66.6 \%$ of species found alive were also found dead (F1), and $61.5 \%$ of the dead ones were recorded alive (F2) (Tab. IV). The similarity of these values is probably related to the same richness observed $(S=11)$ for both assemblages (Tabs. II, III). It is important to emphasize here that the assemblages found in the MS site showed significantly higher fidelity $(p=0.012)$ than
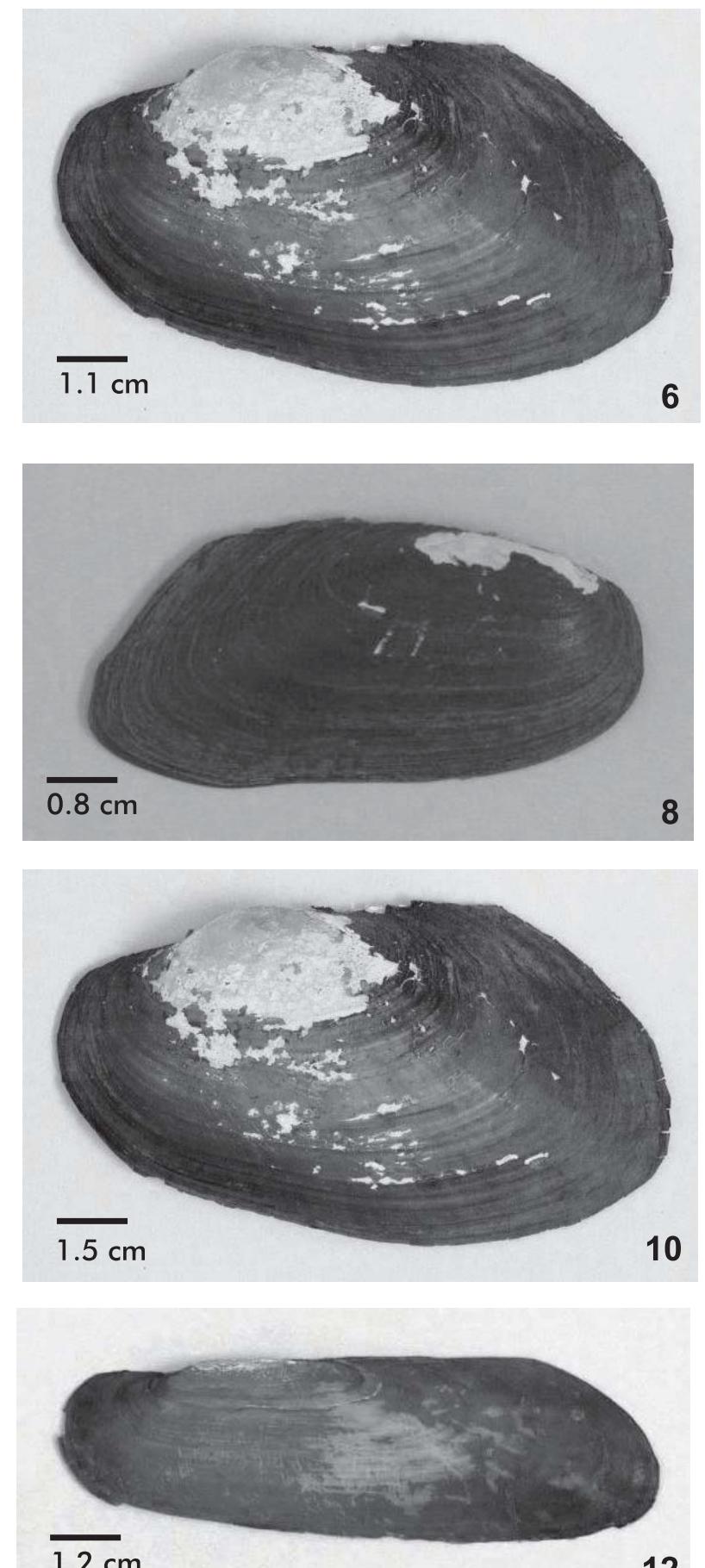

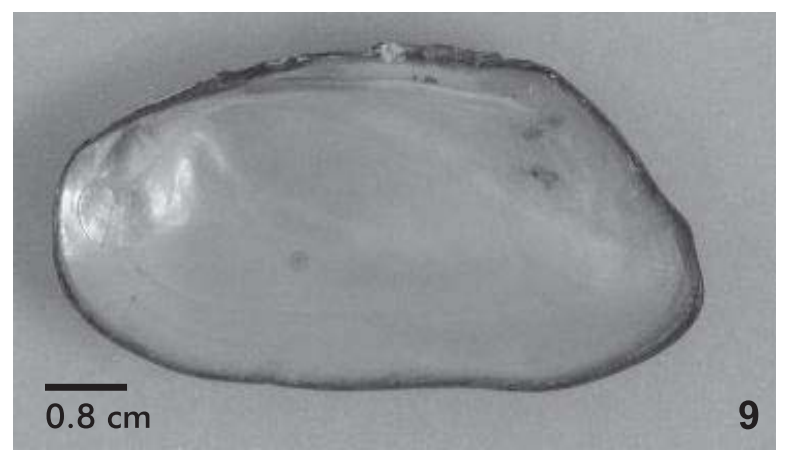

the assemblages of the SS site. For example, nine species (P. canaliculata, $P$. aff. orbigny, Potamolithus sp., Biomphalaria sp., D. delodontus wymani, C. fluminea, C. largillierti, E. klappenbachi and P. sterkianum) found dead in the assemblages of the meandering-sector were also recorded in the live assemblages (F2). For the dead specimens belonging to live species (F3), from the MS site, fidelity was $86.9 \%$, and significantly higher $(\mathrm{p}=0.009)$,
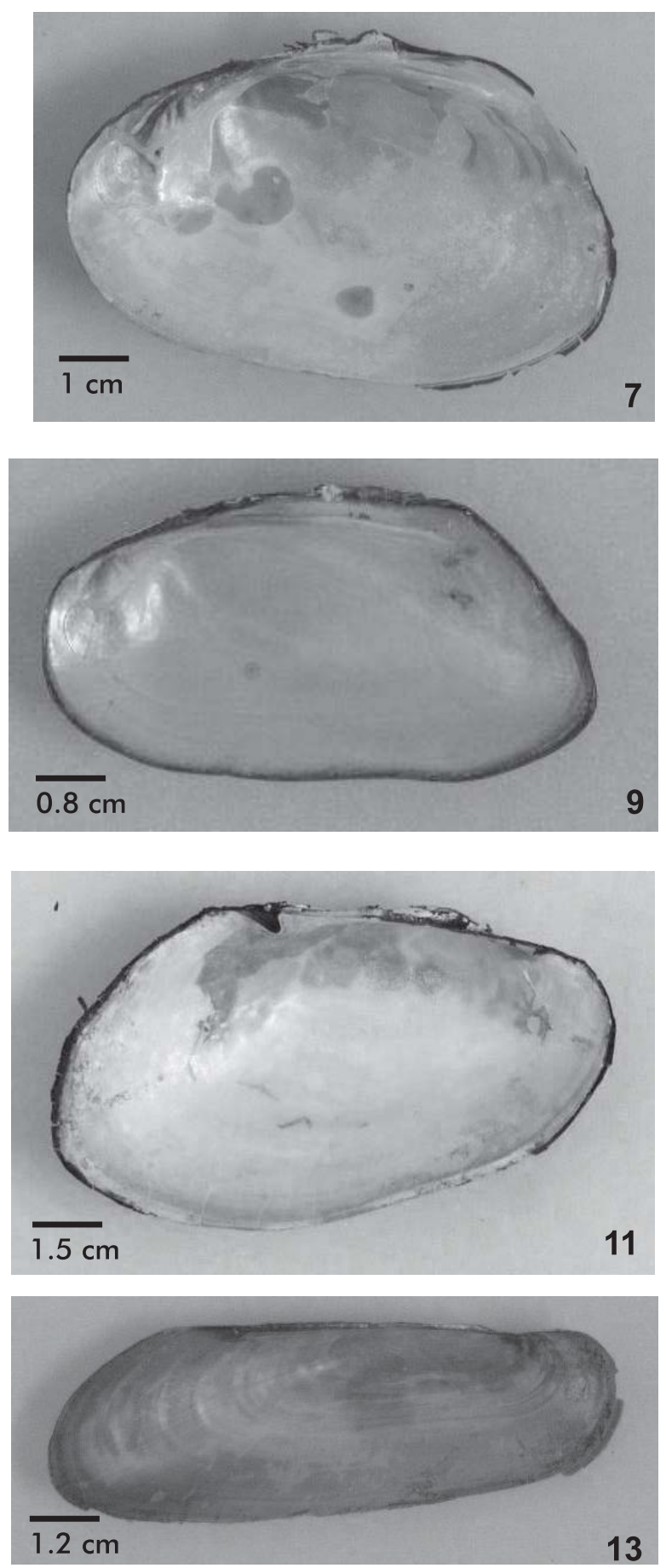

Figs. 6-13. Bivalves of the Touro Passo River. Diplodon delodontus wymani, right valve: 6, external view; 7, internal view; Diplodon parallelopipedon, right valve: 8, external view; 9, internal view; Anodontites trapesialis forbesianus, left valve: 10, external view; 11, internal view; Mycetopoda siliquosa, left valve: 12, external view; 13, internal view. 
than the assemblages from the SS site. The similarity among the live/dead fidelities (F1) of both sectors was not significantly different $(\mathrm{p}=0.911)$.

Among the bivalve species found by Bombin (1976) and Édson Oliveira (pers. comm.) for the Touro Passo River, some were not recorded in the studied life assemblages, including: Leila blainvilliana (Lea, 1834), Diplodon variabilis (Maton, 1811), D. parallelopipedon, D. rhuacoicus (Orbigny, 1835), Castalia ambigua inflata (Orbigny, 1835), A. tenebricosus, A. ferrarisi (Orbigny, 1835), A. patagonicus, A. trapezeus (Spix, 1827), Mycetopoda legumen (Martens, 1888), M. siliquosa, M. minuana and Monocondylaea corrientesensis (Orbigny, 1835). However, some of them (D. delodontus wymani, D. parallelopipedon, C. fluminea, N. limosa) were assigned in the studied death assemblages. Yet, it is noteworthy that some bivalve species in the studied molluscan fauna (e.g., A. ferrarisi, A. trapesialis forbesianus, L. blainvilliana, M. legumen and $M$. siliquosa) are declining or even disappearing (MANSUR et al., 2003a), due to human induced environmental changes and/or due to competition with alien species $[C$. fluminea and Limnoperna fortunei (Dunker, 1857)] (MANSUR \& VeITENHEIMER-MENDEs, 1976; MANsur et al., 2003b).

The low levels of richness observed may be a result of the short extension of the Touro Passo River $(\sim 55 \mathrm{~km})$, and the typical water volume oscillation along the seasons (Bombin, 1976). This may generate adverse environmental conditions to some species.

As far as the ecological fidelity, the presence of a high number of species classified as preferential is an unexpected characteristic of the studied life assemblages. This is because freshwater mollusks are usually considered generalists (DuARTE \& Diefenbach, 1994; MAnsur et al., 1994; Pereira et al., 2000a), and thus not restricted to a particular fluvial environment. The unique

Table IV. Index of similarity and quantitative fidelity at substation, station and river-scale, according to questions $\mathrm{F} 1\left(\mathrm{~N}_{\mathrm{S}} \times 100 / \mathrm{N}_{\mathrm{L}}+\right.$ $\left.\mathrm{N}_{\mathrm{S}}\right), \mathrm{F} 2\left(\mathrm{~N}_{\mathrm{S}} \times 100 / \mathrm{N}_{\mathrm{D}}+\mathrm{N}_{\mathrm{S}}\right)$ and $\mathrm{F} 3$ [(dead individuals of $\left.\mathrm{N}_{\mathrm{S}} \times 100\right)$ / (dead individuals of $\mathrm{N}_{\mathrm{D}}+\mathrm{N}_{\mathrm{S}}$ )], between the live and death assemblages collected in the middle course of the Touro Passo River, Uruguaiana, RS.

\begin{tabular}{lcccc}
\hline Station/ & \multicolumn{3}{c}{ life assemblage x death assemblage } \\
\cline { 2 - 5 } Substation & $\begin{array}{c}\text { Index of } \\
\text { Similarity }\end{array}$ & F1 & F2 & F3 \\
\hline SS01 & 0.28 & 100 & 16.6 & 40.7 \\
SS02 & 0.28 & 100 & 16.6 & 34.2 \\
SS03 & 0.50 & 50 & 50 & 66.6 \\
SS04 & 0.66 & 100 & 25 & 53.8 \\
SS05 & 0.50 & 66.7 & 40 & 29.2 \\
SS Total & 0.50 & 60 & 30 & 67.7 \\
& & & & \\
MS01 & 0.77 & 100 & 71.4 & 77.8 \\
MS02 & 0.90 & 83.3 & 100 & 87.6 \\
MS03 & 0.66 & 100 & 50 & 88.4 \\
MS04 & 0.62 & 71.4 & 55.5 & 81.6 \\
MS05 & 0.60 & 60 & 60 & 81.8 \\
MS Total & 0.73 & 66.6 & 61.5 & 86.9 \\
\hline TOTAL & 0.72 & 60 & 47.3 & 72.3 \\
\hline
\end{tabular}

strange species found (Biomphalaria sp.) is a representative of a genus whose species are common in a wide variety of lentic environments. Species of Biomphalaria are especially common in settings characterized by slow current and marked by anthropogenic influence (PEREIRA et al., 2000b). The shells of Biomphalaria sp. might have been carried out into the river from vicinal lentic settings (e.g., AMS), during floodings. Similar lateral shell transport was already recorded for this genus by CHIEFFI \& MoRetTi (1979). The species classified as indifferent $(P$. canaliculata) inhabits lotic and lentic environments, and also shows a wide environmental distribution. This species can cope with the dry conditions among seasons, and eutrophic conditions (CAZZANiga, 1987; Estebenet \& CAZZANiga, 1992; Martín et al., 2001; Pereira et al., 2000a, 2001). The presence of a large number of species assigned as preferentials indicates the high ecological fidelity of the biocoenosis of the Touro Passo River.

Among the three species recorded in the AMS site, the dominant species ( $G$. moricandi), and also Biomphalaria sp., are commonly associated with aquatic vegetation (BONETTO et al., 1982; SANTOS \& FREITAS, 1986; Lanzer, 1996; Pereira et al., 2000a,b). Therefore, environments such as the abandoned meander could be a favorable place to species assigned as strange or indifferent to thrive. These settings could also act as a place to shell dispersion to other nearby environments as well.

It is important to emphasize that the taxonomic composition of the studied molluscan assemblages is not the one expected for a fourth-order river. In such rivers, according to the River Continumm Concept, the richness and abundance of scrapers/grazers (gastropod) and collectors (bivalve) species are expected to be similar (Allan, 1996; Naiman \& Bilby, 1998). In general, the predominance of the latter suggests the presence of large sections and/or the proximity of the river's mouth (NAIMAN \& BILBY, 1998).

At the station-level, the higher richness and abundance showed by the substations of the MS site, although not significantly different (see results), seems a reflection of the higher habitat diversity of this river sector. This includes settings with different bottom types, variable current velocities (lentic and lotic facies) and the ephemerous presence of isolated water pools. Also, the higher Shannon-Wiener index obtained (Tab. IV) suggests that the MS life assemblages are more homogeneous, regarding the species frequency.

In general, the species $P$. aff. orbigny, Potamolithus sp. and $C$. largillierti were dominant in the MS life assemblages and in the whole Touro Passo River as well. The substations MS02, MS04 and MS05 showed, simultaneously, the three species, reinforcing their ecological preference for sites with coarse sands, shallow water conditions with intermitent water flows (ITUARTE, 1994; López Armengol \& Darrigran, 1998). In the straight-sector, only one species ( $P$. aff. orbigny) is dominant. This was recorded in the substations SS01, SS02 and SS03, where silt-dominated bottoms (sometimes with coarse to fine sands), no aquatic plants, and strong and continuous currents prevail (Tab. I). These 
environmental conditions seem to favor the presence of species belonging to the genus Potamolithus (Di Persia \& Olazarri, 1986; LóPez Armengol \& Darrigran, 1998; Pereira et al., 2000a,b).

Several previous studies in marine (KIDwell \& Bosence, 1991; Kidwell \& Flessa, 1995; Best \& Kidwell, 2000; KOWALEWSKI et al., 2003) and freshwater (BRIGGS et al., 1990; WARREN, 1991; CUMMINS, 1994) environments suggest that the richness and the abundance are usually higher in the thanatocoenoses than in the biocoenoses. However, the richness of the studied thanatocoenoses is not remarkable different of the biocoenoses (Tabs. II, III). In fact, both share nine species at river-scale, differing only by the presence of the utmost four species (Heleobia aff. bertoniana, D. parallelopipedon, $M$. siliquosa and $N$. $\operatorname{limos} a$ ). The abundance of the thanatocoenoses was also lower than that already reported in the literature. This may reflect the differences in the sedimentary regime of the studied freshwater environments. Due to the differences in the sedimentary processes (e.g., net sedimentation rate) shell accumulation rates in freshwater environments are usually lower than in the shelf marine environments (Peterson, 1976; Cohen, 1989; Briggs et al., 1990; Warren, 1991; Cummins, 1994; Kidwell \& FLESSA, 1995).

Study in reservoirs, east-central Ohio, USA (see Cummins, 1994), showed that death and life assemblages of Unionacea exhibit high ranges of rank order correlation ( $r s=-0.06$ to 0.57 ), especially to the non-regulated courses. On the other hand, the regulated ones showed lower ranges, but with positive and high values at site-scale (rs=0.67 a 0.89, Cummins, 1994). These differences are interpreted as response to the water energy, particularly to the low-energy conditions that prevails in the reservoirs (Cummins, 1994). At river-scale, the rank order correlation recorded by Cummins (1994) was rs=0.64. Similarly, the rank order correlation recorded to the Touro Passo River was rs $=0.56$. Hence, despite of the unexpected values of the richness and abundance of the studied death assemblages, the ranking of dominance was similar to that previously recorded in the literature for other freshwater shelly thanatocoenoses (WARREN, 1991; Cummins, 1994). Additionally, our data also show that among the six dominant species (Potamolithus sp., P. aff. orbigny, C. largillierti, Biomphalaria sp., C. fluminea and $P$. canaliculata) of the thanatocoenoses of the Touro Passo River, five (the exception is Biomphalaria sp.) are also dominants in the biocoenoses. Corbicula largillierti shows the third order position in both assemblages. This is in accordance with the general idea that the ranking of dominance at river-scale is preserved in the thanatocoenosis.

The index of similarity among the live and death assemblages of the Touro Passo River was high (0.72), and similar to that observed by Cummins (1994) for the non-regulated areas of Ohio reservoirs (0.67 to 0.70). In the Touro Passo River, the recorded indexes for each collecting stations were $0.50(\mathrm{SS})$ and $0.73(\mathrm{MS})$, ranging from 0.28 (SS01) to 0.90 (MS02) among the substations (Tab. IV). At station-level, the differences are probably related to the less energetic conditions that prevail in the meandering-sector. At substation-level, the differences might be associated with particular local conditions (e.g., margin declivity, bottom type and the presence/ausence of terrestrial and aquatic plants) (see also BRIGGs et al., 1990). Consequently, despite of the discontinuous distribution of the species in the sampled death assemblages from the SS and MS sectors, the thanatocoenoses yielded nearly similar abundance and richness with the local life assemblages.
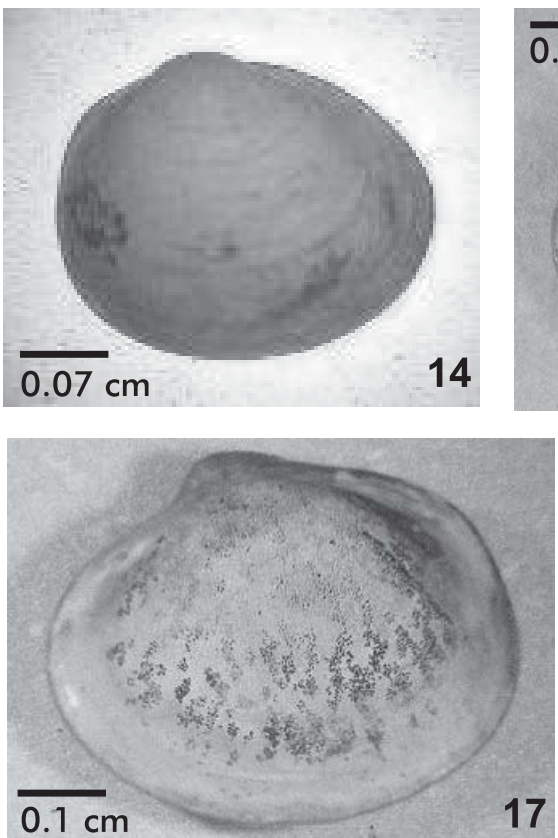
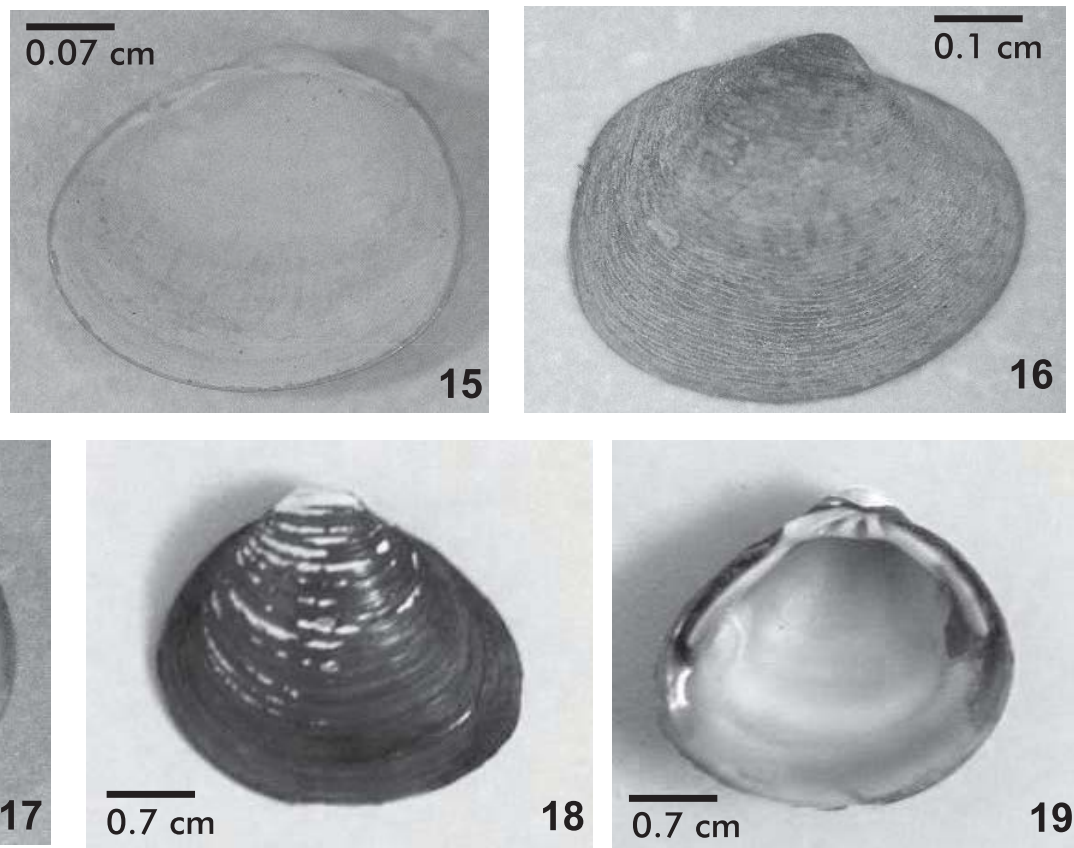

Figs. 14-19. Bivalves of the Touro Passo River. Pisidium sterkianum, right valve: 14, external view; 15, internal view; Eupera klappenbachi, left valve: 16, external view; 17, internal view; Corbicula largillierti, left valve: 18, external view; 19, internal view. 
Our fidelity (F1, F2) results (Tab. IV), at river-scale, are somewhat distinct of those previously reported in the literature. For example, Cummins (1994) obtained F1 and F2 values of $83 \%$ to $100 \%$, and of $50 \%$ to $58 \%$, respectively for freshwater assemblages of US-reservoirs. Other authors (KIDwELl \& FLESSA, 1995) noted that, as general condition, assemblages generated under freshwater environments yield the following values: F1 $(=95 \%)$, and F2 $(=55 \%)$. Assemblages of the Touro Passo River, yielded $\mathrm{F} 1$ values as low as $60 \%$, and $\mathrm{F} 2$ values $(=47.3 \%)$, nearly comparable with those previously reported by CUMMINS (1994) and KIDwELL \& FLESSA (1995). However, it should be stressed that the slightly low F1 and F2 values noted here may be due to the adoption of distinct methodological decisions among studies, including exhaustive analyses, which include fragments (Briggs et al., 1990; Cummins, 1994; Kowalewski et al., 2003), and the use of target taxa, especially among bivalve mollusks (Unionacea) (WARREN, 1991; CuMMINS, 1994). Besides this, it should be also remembered that the sedimentary environments are not the same for all those studies. Hence, the differences may reflect the distinct sedimentary/taphonomic processes that operate in each environment (see also PIP, 1988; BRIGGs et al., 1990). On the other hand, the low number of species found alive that are also found dead (F1), can be attributed to the factors that may control the abundance and/or the temporal- and spatial-mixing of the shells. These include the downstream drifting and the fast dissolution of the shells under freshwater conditions (COHEN, 1989; BRIGGS et al., 1990; WARREN, 1991). However, it is also important to emphasize that the numerically dominant species are more easily recorded than the others, as indicated by the Spearman rank correlation and F3 values (Tab. IV).

At station-scale, the higher percentages of dead species also found in the life assemblages (F2) and the number of dead individuals representing species also found alive (F3) recorded in the MS site could be associated with the continuous downstream flow, from the straight-sector, that probably transports the shells, and with the physical properties prevailing in the meandering-sector. In the latter, the presence of coarse bottoms and riparian vegetation (Tab. I) may provide stable conditions, allowing the trapping of the shells, favoring its accumulation (see BRIGGS et al., 1990, for a similar example).

At river-scale, $72 \%$ of the dead individuals represented species found alive (F3), while at substationscale, $\mathrm{F} 3$ values range from $29.2 \%$ to $87.6 \%$. These results are in the range of the data available in the literature. For example, Cummins (1994) reported F3 values ranging from $58 \%$ to $97 \%$ to the non-regulated streams of the North America reservoirs. KIDWELL \& Bosence (1991) assigned F3 values ranging from $70 \%$ to $90 \%$ for assemblages generated in marine environments.

\section{CONCLUSIONS}

The taxonomic composition of the analyzed molluscan biocoenoses of the Touro Passo River is characteristic of the lotic settings that prevail in the study area. However, it does not reflect the river-order, and is not consistent with the River Continuum Concept.

Ecological attributes (abundance, richness and diversity) of the studied biocoenoses are not sensitive to particular environmental conditions (e.g., channel morphology). However, they may reflect the complex interaction among the natural factors, including the presence/absence of aquatic and terrestrial vegetation, differences in current velocity and bottom type of the different studied river-sectors.

The rank order of the dominant species of the Touro Passo River in the thanatocoenoses could be used to infer the ranking of the most abundant species in the original life assemblages.

The low number of species found alive that were also found dead (F1) in the studied assemblages may be a result of the lotic environmental conditions prevailing in the Touro Passo River. This may favor quick shell dissolution, avoiding the accumulation of the noncontemporaneous remains. Hence, rates of time-averaging may be low for those assemblages.

The low values of dead/live agreement reported here are quite similar to that already published in the freshwater molluscan literature. Hence, the studied death assemblages are not faithful mirrors of the original biocoenoses. However, the number of dead individuals that are also found alive (F3) is high. Consequently, this may be a useful tool in the reconstruction of some particular attributes of the original biocoenoses (e.g., the dominant species and their ranking order).

Acknowledgments. The authors are indebted to Dr. Édison Vicente Oliveira (PUC/RS), for his assistance during field trips, and to Dr. Renata Guimarães Netto (UNISINOS) and Dr. Inga L. Veitenheimer-Mendes (UFRGS), for the valuable suggestions and/or critical review of the initial proposal of this project. The authors thank Dr. Maria Cristina Pons da Silva (ULBRA), for identification of the specimens of Potamolithus and Heleobia. Dr. Rocco Alfredo Di Mare (UFSM) helped with the statistical analysis. Malacological materials, charts and maps were borrowed of Dr. Átila Augusto Stock da Rosa and Dr. Saul Eduardo Seiguer Milder (UFSM); they also made useful comments on early drafts of this manuscript. Fernanda Stücker (UFSM) helped with the drawing of the figure 1. Finally, we thank the anonymous reviewers for the useful comments on this paper.

\section{REFERENCES}

Allan, J. D. 1996. Stream ecology: structure and function of running waters. London, Chapman \& Hall. 388p.

Behrensmeyer, A. K.; Kidwell, S. M. \& Gastaldo, R. A. 2000. Taphonomy and paleobiology. Paleobiology, Supl., 26(4): 103-147.

Best, M. M. R. \& Kidwell, S. M. 2000. Bivalve taphonomy in tropical mixed siliciclastic-carbonate settings. II- Effect of bivalve life habitats and shell types. Paleobiology 26(1): 103-115.

Bombin, M. 1976. Modelo paleoecológico evolutivo para o Neoquartenário da região da campanha oeste do Rio Grande do Sul, Brasil: a Formação Touro Passo, seu conteúdo fossilífero e a pedogênese pós-deposicional. Comunicações do Museu da PUC/RS 15:1-90.

Bonetto, A. A.; Bechara, J. A. \& Tassara, M. P. 1982. Los moluscos de la família Planorbidae en el área del río Paraná medio. Physis 41(100): 1-6.

Briggs, D. J.; Gilbertson, D. D. \& Harris, A. L. 1990. Molluscan taphonomy in a braided river environment and its implications for studies of Quaternary cold-stage river deposits. Journal of Biogeography 17:623-637.

Cazzaniga, N. J. 1987. Pomacea canaliculata (Lamarck, 1801) 
en Catamarca (Argentina) y un comentario sobre Ampullaria catamarcensis Sowerby, 1874 (Gastropoda, Ampullariidae). Iheringia, Série Zoologia, (66):43-68.

Chieffi, P. P. \& Moretti, I. G. 1979. Flutuação mensal na densidade de populações malacológicas em criadouro natural do município de Londrina, Estado do Paraná, Brasil. Revista do Instituto Adolfo Lutz 39(1):45-50.

Christofoletti, A. 1980. Geomorfologia. $2^{\text {a }}$ ed. São Paulo, Edgard Blücher. $149 \mathrm{p}$.

Cohen, A. S. 1989. The taphonomy of gastropod shell accumulations in large lakes: an example from Lake Tanganyka, Africa. Paleobiology 15(1):26-45.

Cummins, R. H. 1994. Taphonomic process in modern freshwater molluscan death assemblages: implications for the freshwater fossil record. Palaeogeography, Palaeoclimatology, Palaeoecology 108:55-73.

Dajoz, R. 1978. Ecologia geral. $3^{\mathrm{a}}$ ed. Petrópolis, Vozes. 472p.

Di Persia, D. H. \& Olazarri, J. 1986. Zoobenthos of the Uruguay system. In: Davies, B. R. \& W ALKer, K. F. eds. The ecology of River System. Drodrecht, Junk Publishers, XVIII. p.623-629.

Duarte, M. M. \& Diefenbach, C. O. 1994. Microdistribution and abundance of freshwater mussels (Mollusca: Unionacea and Corbiculacea) in Suzana Lake, Southern Brazil. Studies on Neotropical Fauna and Environment 29(4):233-250.

Estebenet, A. L. \& Cazzaniga, N. J. 1992. Growth and demography of Pomacea canaliculata (Gastropoda: Ampullariidae) under laboratory conditions. Malacological Review 25:1-12.

Focht, T. \& Veitenheimer-Mendes, I. L. 2001. Distribuição sazonal e reprodução de Neocorbicula limosa (Maton) (Bivalvia, Corbiculidae) no lago Guaíba, Rio Grande do Sul, Brasil Revista Brasileira de Zoologia 18(1):35-43

Ituarte, C. F. 1984. Aspectos biológicos de las poblaciones de Corbicula largillierti Philippi (Mollusca Pelecypoda) en el río de la Plata. Revista del Museo de La Plata 13(143):231-247. . 1994. Corbicula and Neocorbicula (Bivalvia: Corbiculidae) in the Paraná, Uruguay, and rio de la Plata basins. The Nautilus 107(4):129-135.

Kidwell, S. M. 2001. Preservation of species abundance in marine death assemblages. Science 294:1091-1094.

Kidwell, S. M. \& Bosence, D. W. J. 1991. Taphonomy and timeaveraging of marine shelly faunas. In: Allison, P. A. \& BRIGGS, D. E. eds. Taphonomy, releasing the data locked in the fossil record. Topics in Geobiology. New York, Plenum. p. 115-209.

Kidwell, S. M. \& Flessa, K. W. 1995. The quality of the fossil record: populations, species and communities. Annual Review of Ecology Systematics Genus 26:269-299.

Kowalewski, M.; Carroll, M.; Casazza, L.; Gupta, N. S.; Hannisdal, B.; Hendy, A; Krause, R. A., Jr.; LaBarbera, M.; Lazo, D. G.; Messina, C.; Puchalski, S.; Rothfus, T. A.; Sälgeback, J.; Stempien, J.; Terry, R. C. \& Tomasovych, A. 2003. Quantitative fidelity of Brachiopod-Mollusk assemblages from modern subtidal environments of San Juan Islands, USA. Journal of Taphonomy 1(1):43-65.

LANZER, R. M. 1991. Duas novas espécies de Ancylidae (Gastropoda: Basommatophora) para o sul do Brasil. Revista Brasileira de Biologia 51(4):703-719.

. 1996. Ancylidae (Gastropoda, Basommatophora) na América do Sul: sistemática e distribuição. Revista Brasileira de Zoologia 13(1):175-210.

Lanzer, R. M. \& Veintenheimer-Mendes, I. L. 1985. Aspectos morfológicos e biológicos de uma população de Gundlachia concentrica (Orbigny, 1835) (Mollusca, Ancylidae) de um açude do sul do Brasil. Iheringia, Série Zoologia, (65):41-56.

Leite, P. F. 2002. Contribuição ao conhecimento fitoecológico do sul do Brasil. Ciência e Ambiente 24:51-73.

Lopes-Pitoni, V. L.; Veitenheimer-Mendes, I. L.; Lanzer, R. M. \& Silva, M. C. P. 1984. Nota sobre a estrutura faunística do plêuston em um açude no morro Santana, Porto Alegre, Rio Grande do Sul, Brasil. Ciência e Cultura 36(2):245-248.

López Armengol, M. F. \& Darrigran, G. 1998. Distribución del género neotropical Potamolithus Pilsbry y Rush, 1896 (Gastropoda: Hydrobiidae) en el estuario del Rio de la Plata. Iberus 16(2):67-74.

Magurran, A. E. 1988. Ecological diversity and its measurement. Croom Helm, New South Wales. 179p.

Mansur, M. C. D. \& Garces, L. M. M. P. 1988. Ocorrência e densidade de Corbicula fluminea (Mueller, 1774) e Neocorbicula limosa (Maton, 1811) na estação ecológica do Taim e áreas adjacentes, Rio Grande do Sul, Brasil (Mollusca, Bivalvia, Corbiculidade). Iheringia, Série Zoologia, (68):99-115.

Mansur, M. C. D. \& Veitenheimer-Mendes, I. L. 1976. O futuro dos moluscos bivalves no rio Guaíba. Iheringia, Série Zoologia, (5):5-6.

Mansur, M. C. D.; Anflor-De-Oliveira, L. M. \& Almeida-Caon, J. E. M. 2001. Pisidium punctiferum (Bivalvia, Sphaeriidae) dados ecológicos e densidade populacional no arroio Bom Jardim, Rio Grande do Sul, Brasil. Biociências 9(1):81-97.

Mansur, M. C. D.; Schulz, C. \& Garces, L. M. M. 1987. Moluscos bivalves de água doce: identificação dos gêneros do sul e leste do Brasil. Acta Biologica Leopoldensia 2:181-202.

Mansur, M. C. D.; Valer, R. M. \& Aires, N. C. M. 1994. Distribuição e preferências ambientais dos moluscos bivalves do açude do parque de proteção ambiental Copesul, município de Triunfo Rio Grande do Sul, Brasil. Biociências 2(1):27-45.

Mansur, M. C. D.; Veitenheimer-Mendes, I. L. \& Almeida-Caon, J. E. M. 1988. Mollusca, Bivalvia de um trecho do curso inferior do rio Jacuí, Rio Grande do Sul, Brasil. Iheringia, Série Zoologia, (67):67-108

Mansur, M. C. D.; Schulz, C.; Silva, M. G. O. \& Campos-Velho, N. M. R. 1991. Moluscos bivalves límnicos da estação ecológica do Taim e áreas adjacentes, Rio Grande do Sul, Brasil. Iheringia, Série Zoologia, (71):43-58.

Mansur, M. C. D.; Heydrich, I.; Pereira, D.; Richinitti, L. M. Z.; Tarasconi, J. C. \& Rios, E. C. 2003a. Moluscos. In: Fontana, C. S.; Bencke, G. A. \& Reis, R. E. orgs. Livro vermelho da fauna ameaçada de extinção no Rio Grande do Sul. Porto Alegre, EDIPUCRS. p.49-71.

Mansur, M. C. D.; Santos, C. P.; Darrigran, G.; Heydrich, I.; Calil, C. T. \& Cardoso, F. R. 2003b. Primeiros dados qualiquantitativos do mexilhão dourado, Limnoperna fortunei (Dunker), no delta do Jacuí, no lago Guaíba e na laguna dos Patos, Rio Grande do Sul, Brasil e alguns aspectos de sua invasão no novo ambiente. Revista Brasileira de Zoologia 20(1):75-84.

Martín, P. R.; Estebenet, A. E. \& Cazzaniga, N. J. 2001. Factors affecting the distribution of Pomacea canaliculata (Gastropoda: Ampullariidae) along its southernmost natural limit. Malacologia 43(1-2): 13-23.

Martinez, S. \& Rojas, A. 2004. Quaternary continental mollusks from Northern Uruguay: distribution and paleoecology. Quaternary International 114(1):123-128.

Moreno, J. A. 1961. Clima do Rio Grande do Sul. Porto Alegre, Secretaria da Agricultura. 43p.

Naiman, R. J. \& Bilby, R. E. 1998. River ecology and management. New York, Springer. 705p.

Odum, E. P. 1988. Ecologia. Rio de Janeiro, Guanabara Koogan. 434p.

Oliveira, E. V. \& Milder, S. E. S. 1990. Considerações preliminares sobre uma nova fauna de moluscos fósseis da Formação Touro Passo (Pleistoceno Superior - Holoceno): observações estratigráficas e paleoecológicas. Veritas 35(137):121-129.

Oliveira, L. M. A. \& Mansur, M. C. D. 2001. Pisidium punctiferum (Mollusca, Bivalvia, Sphaeriidae): aspectos do seu desenvolvimento em amostras da população do arroio Bom Jardim, da bacia do rio Caí, Rio Grande do Sul, Brasil. Biociências 9(1):141-154.

Parodiz, J. J. \& Hennings, L. 1965. The Neocorbicula (Mollusca, Pelecypoda) of the Paraná-Uruguay Basin, South America. Annals of Carnegie Museum 38(3):69-96.

Pereira, D.; Konrad, H. G. \& Paloski, N. I. 2000a. Gastrópodos límnicos da bacia do rio Camaquã, RS, Brasil. Acta Biologica Leopoldensia 22(1):55-66.

Pereira, D.; Inda, L. A.; Consoni, J. M. \& Konrad, H. G. 2001. Composição e abundância de espécies de moluscos do bentos marginal da microbacia do arroio Capivara, Triunfo, RS, Brasil. Biociências 9(1):3-20.

Pereira, D.; Veitenheimer-Mendes, I. L.; Mansur, M. C. D. \& Silva, M. C. P. 2000b. Malacofauna límnica do sistema de irrigação da microbacia do arroio Capivara, Triunfo, RS, Brasil. Biociências 8(1):137-157. 
Peterson, C. H. 1976. Relative abundances of living and dead mollusks in two Californian lagoons. Lethaia 9:137-148.

PIP, E. 1988. Differential attrition of moluscan shells in freshwater sediments. Canadian Journal Earth Sciences 25:68-73.

Porto, M. L. 2002. Os campos sulinos: sustentabilidade e manejo. Ciência e Ambiente 24:119-138.

Santos, M. B. L. \& Freitas, J. R. 1986. Consumo quantitativo e qualitativo de perifíton colonizado em substrato artificial, por Biomphalaria tenagophila (Gastropoda, Planorbidae). Memórias do Instituto Oswaldo Cruz 81(4):359-364.

SArtori, M. G. B. 2003. A dinâmica do clima do Rio Grande do Sul: indução empírica e conhecimento científico. Terra Livre 1(20): 27-49.

Silva, M. C. P. \& Thomé, J. W. 1981. Ocorrência de Littoridina piscium (Orbigny, 1835) no açude do morro Santana, Porto Alegre, RS (Hydrobiidae, Prosobranchia). Revista Brasileira de Biologia 41(2):359-399.

Strahler, A. N. \& Strahler, A. H. 1989. Geografia física. $3^{\text {a }}$ ed Barcelona, Omega. 550p.
Veitenheimer, I. L. \& Mansur, M. C. D. 1978. Morfologia, histologia e ecologia de Mycetopoda legumen (Martens, 1888) (Bivalvia, Mycetopodidae). Iheringia, Série Zoologia, (52):33-71.

Veitenheimer-Mendes, I. L.; Lopes-Pitoni, V. L.; Lanzer, R. M. \& Silva, M. C. P. 1990. Zoobenthos litorâneos de um açude sulbrasileiro. Revista Brasileira de Biologia 50(1):7-14.

Veitenheimer-Mendes, I. L.; Lopes-Pitoni, V. L.; Silva, M. C. P.; Almeida-Caon, J. E. \& Schröeder-Pfeifer, N. T. 1992. Moluscos (Gastropoda e Bivalvia) ocorrentes nas nascentes do rio Gravataí, Rio Grande do Sul, Brasil. Iheringia, Série Zoologia, (73):69-76.

Walker, K. R. \& Bambach, R. K. 1971. The significance of fossil assemblages from fine-grained sediments: time-averaged communities. Geological Society of America (Abstracts with Programs) 3:783-784.

WARren, R. E. 1991. Ozarkian fresh-water mussels (Unionoidea) in the upper eleven point river, Missouri. American Malacological Bulletin 8(2):131-137. 